\title{
Pemanfaatan Tepung Daun Apu-apu (Pistia stratiotes) dalam Ransum Basal terhadap Organ Pencernaan Ayam Ras Pedaging
}

\author{
R. Sitompul, E. Erwan* \& E. Saleh \\ Program Studi Peternakan, Fakultas Pertanian dan Peternakan, UIN Sultan Syarif Kasim \\ JL. HR. Soebrantas KM.15 Simpang Baru Panam Pekanbaru \\ Email : erwan_edi@yahoo.com
}

(Diterima : 19 Juli 2019 ; Disetujui : 22 Januari 2020)

\begin{abstract}
Water lettuce meal (Pistia stratiotes) is the weed that has potential as animal feed due to it contain crude protein and energy metabolism which potentially as poultry feed. The aims of this study wasto determine the weight and length of digestive organs including proventriculus, ventriculus, small intestine in broiler chicken given of water lettuce meal (WLM) in ratios. The research design of this study was a completely randomized design (CRD) with five treatments and four replications. The treatments consisted of T0 (commercial feed without WLM), T1 (ration with 0\% WLM), T2 (ration with 5\% WLM), T3 (ration with 10\% WLM) and T4 (ration with 15\% WLM). The experimental animal used were broiler DOC until the age of 35 days old were kept in 20 cages and each cage consisted of 3 broiler chickens. The parameters measured were proventriculus weight, ventriculus weight, small intestine weight and length of the small intestine. The results showed that there was no significant effects among treatments on all parameters. The conclusions of the study that the use of indicate that WLM could be used as feed up to $15 \%$ in ration without affecting their the proventriculus weight, ventriculus weight, small intestine weight and length small intestine broiler chickens.
\end{abstract}

Key words: Pistia stratiotes, proventriculus, ventriculus, small intestine, broilers

\section{PENDAHULUAN}

Ayam ras pedaging yang juga dikenal dengan ayam broiler adalah salah satu sumber protein hewani yang relatif murah jika dibandingkan dengan daging yang lain khususnya ruminansia. Ayam ras pedaging memiliki beberapa keunggulan diantaranya dapat dipanen dibawah umur 5 minggu karena pertumbuhannya relatif cepat juga memiliki rata-rata bobot badan sekitar 1,5 $\mathrm{kg}$ (Situmorang et al., 2013). Salah satu faktor yang menentukan keuntungan besar dalam pemeliharaan ayam broiler adalah kualitas ransum yang memenuhi standar kebutuhan yang diperlukan sesuai dengan periode pemeliharaannya.

Kriteria ransum yang baik diantaranya memiliki sifat palatabel (disukai ternak), mudah didapat, tidak mudah rusak selama penyimpanan, kandungan nutrisi yang baik, menghasilkan pertambahan bobot badan yang tinggi, mudah dicerna, serta harganya murah. Namun demikian, permasalahan yang sering muncul adalah mahalnya harga ransum yang mencapai $70-80 \%$ dari total biaya produksi. Sebagai akibat dari permasalahan tersebut maka diperlukan upaya agar penggunaan pakan yang ada lebih efektif dan efisien (Sari dan Ginting, 2012). Salah satu cara untuk mengurangi biaya yang dikeluarkan terutama yang berasal dari ransum adalah dengan cara pemanfaatan limbah pertanian atau gulma yang salah satunya adalah tanaman apu-apu sebagai pakan ayam broiler.

Pada umumnya tanaman apuapu tumbuh didaerah tropis dan tumbuh diatas permukaan air yang tenang ataupun mengalir relatif lambat. Ternak unggas dan ikan juga dikenal menyukai tanaman apu-apu (Sutama, 2005). Tanaman apuapu dapat tumbuh liar didaerah rawa, sungai, danau atau genangan air, sehingga dianggap dapat menyebabkan kerusakan lingkungan. Tanaman ini memiliki potensi untuk dijadikan sebagai salah satu bahan campuran ransum unggas dikarenakan kandungan potein kasarnya sekitar 23,57\% (Budiarti, 2018). Selain itu, kelebihan lain tanaman ini adalah mengandung hampir seluruh asam amino esensial kecuali asam amino triptopan dan methionin (Rusoff et al., 1980). Jumlah kandungan energi metabolis 
dan asam amino pada tanaman ini cukup bervariasi tergantung pada beberapa faktor misalnya media nutrisi, strain dan mungkin isolat atau clone (Goopy and Murry, 2003).

Salah satu keunggulan yang signifikan daun apu-apu adalah potensinya yang dapat dimanfaatkan sebagai sumber protein pada makanan yang sangat penting sebagai penyusun protein (Rushot et al., 1980). Pemanfaatan daun apu-apu diharapkan dapat menggantikan pakan sumber protein seperti tepung ikan atau tepung kedelai.

Namun demikian, pemanfaatan daun apu-apu sebagai pakan ayam ras pedaging sedikit memiliki kendala yaitu tingginya kandungan serat kasar. Adapun kandungan serat kasar daun apu-apu adalah sekitar $8,8 \%$ sampai 11,0\% (Rushof et al., 1980). Serat kasar merupakan salah satu komponen penyusun dinding sel tumbuhan. Serat kasar terdiri dari lignin, selulosa dan hemiselulosa. Kandungan serat kasar yang relatif tinggi dapat menyebabkan terganggunya proses pencernaan di dalam saluran pencernaan. Korelasi antara kandungan serat kasar dengan kecernaan pakan adalah berbanding terbalik. Kecernaan bahan pakan banyak dipengaruhi oleh organ saluran pencernaan. Umumnya morfologi saluran pencernaan menggambarkan kondisi kesehatan ternak dan kemampuan saluran pencernaan. Performa dan morfologi organ di dalam saluran pencernaan pada unggas juga banyak ditentukan oleh sumber dan jenis serat (Iyayi dkk., 2005). Metode yang dapat digunakan untuk mengetahui kondisi saluran pencernaan adalah melalui pengukuran bobot dan panjang saluran pencernaan.

Selama ini efek penggunaan tanaman apu-apu sebagai bahan penyusun ransum ayam ras pedaging terhadap organ pencernaan masih belum ditemukan, sehingga informasi mengenai tingkat penggunaan dalam pakan ayam masih terbatas. Haustein et al. (1990) melaporkan bahwa daun apu-apu dapat menggantikan sampai $15 \%$ bahan sumber protein, dan dapat mempertahankan performan dan dapat memperbaiki kandungan protein pada telur ayam. Sejalan dengan penelitian tersebut, O'Neill et al. (1996) melaporkan bahwa daun apu-apu tidak efektif diberikan jika lebih besar dari $13 \%$ di dalam ransum ayam ras petelur. Berdasarkan hal tersebut di atas, dilakukan penelitian tentang "Pemanfaatan tepung daun apu-apu (Pistia stratiotes) dalam ransum basal terhadap organ pencernaan ayam ras pedaging".

\section{MATERI DAN METODE}

\section{Waktu dan Tempat}

Penelitian ini telah dilaksanakan pada bulan Juni sampai Juli 2018 di Laboratorium Agriculture Research and Development Station (UARDS) Fakultas Pertanian dan Peternakan Universitas Islam Negeri Sultan Syarif Kasim Riau, Pekanbaru.

\section{Bahan dan Alat}

Bahan yang digunakan pada penelitian yaitu Day Old Chick (DOC) ayam broiler strain Cobb merek CP 707 unsex berjumlah 60 ekor yang berasal dari PT. Charoen Pokphand Indonesia Tbk.

Ransum yang digunakan dalam penelitian ini adalah ransum komersial (kontrol) dan ransum basal ayam ras pedaging fase starter (0-3 minggu) dan fase finisher (3-5 minggu). Bahan yang digunakan adalah jagung giling, dedak, padi, bungkil kedelai, tepung ikan, Tepung Daun Apu-apu (TDA), minyak kelapa, kapur $\left(\mathrm{CaCO}_{3}\right)$ dan Top Mix. Formulasi ransum dibuat dengan menggunakan metode trial and error (cobacoba). Ransum yang digunakan pada kontrol adalah pakan tipe Vivo $311^{\circledR}$ untuk umur 1-21 hari dan Vivo $512^{\circledR}$ untuk umur 22-35 hari, sedangkan komposisi dan kandungan nutrien ransum pada fase starter dan finisher dapat dilihat pada Tabel 2 dan Tabel 3. Komposisi bahan pada ransum penelitian dapat dilihat pada Tabel 1.

Peralatan yang digunakan dalam dalam penelitian ini adalah tempat ransum dan tempat minum, termometer untuk mengukur suhu lingkungan kandang, lampu pemanas, timbangan untuk menimbang berat badan ayam pedaging dan organ pencernaan, semprotan untuk desinfeksi, litter, plastik dan kertas koran bekas untuk menampung feses ayam pedaging, ember 
untuk menampung air, nampan, pisau potong, alat tulis, kamera pocket digital dan alat pengukur.

\section{Metode Penelitian}

Rancangan percobaan yang digunakan dalam penelitian ini adalah Rancangan Acak Lengkap (RAL) terdiri dari 5 perlakuan dan 4 ulangan. Berikut adalah perlakuan penelitan:

T0 = Ransum komersial (Kontrol)

$\mathrm{T} 1=$ Ransum basal + TDA $0 \%$.

$\mathrm{T} 2=$ Ransum basal + TDA 5\% .

$\mathrm{T} 3=$ Ransum basal + TDA 10\%.

$\mathrm{T} 4=$ Ransum basal + TDA 15\%.

\section{Prosedur Penelitian}

\section{Prosedur persiapan kandang}

Sebelum penelitian dimulai dan anak ayam umur sehari (DOC) datang, kandang dibersihkan, dilakukan pengapuran dan peralatan seperti tempat pakan dan tempat minum dibersihkan dan dilakukan desinfektan. Kandang yang sudah higienis dibiarkan selama 7 hari. Penerangan dan pemanas kandang digunakan lampu pijar 75 watt yang ditempatkan pada setiap petakan kandang. Penentuan letak kandang dilakukan dengan pengacakan dan diberi kode pada masing-masing unit kandang sesuai dengan perlakuan yang diberikan untuk mempermudah dalam proses pencatatan.

\section{Prosedur pembuatan tepung daun apu-apu (TDA)}

Prosedur pembuatan tepung daun apuapu, sebagai berikut:

1. Pengumpulan tanaman apu-apu (Pistia stratiotes).

2. Pencucian dan pemisahan daun dan akar

3. Pencacahan tanaman apu-apu dengan ukuran $\pm 2-3 \mathrm{~cm}$.

Tabel 1. Kandungan nutrisi bahan penyusun ransum penelitian

\begin{tabular}{lccccc}
\hline \multicolumn{1}{c}{ Bahan Pakan } & $\begin{array}{c}\text { Bahan Kering } \\
(\%)\end{array}$ & $\begin{array}{c}\text { Protein } \\
(\%)\end{array}$ & $\begin{array}{c}\text { Lemak } \\
(\%)\end{array}$ & $\begin{array}{c}\text { Energi } \\
(\mathrm{Kkal} / \mathrm{kg})\end{array}$ & $\begin{array}{c}\text { Serat } \\
(\%)\end{array}$ \\
\hline Dedak $^{\mathrm{a}}$ & 94,07 & 12,17 & 13,93 & 3231,41 & 8,95 \\
Jagung $^{\mathrm{a}}$ & 94,87 & 9,80 & 4,09 & 3448.80 & 2,85 \\
Bungkil Kedelaic $^{\mathrm{c}}$ & 96,54 & 46,04 & 5,79 & 3109.48 & 5,21 \\
TDA $^{\mathrm{b}}$ & 88,66 & $13,06^{*}$ & 2,15 & 2778,55 & 21,86 \\
Tepung Ikan $^{\mathrm{c}}$ & $91,58^{\mathrm{a}}$ & 55,00 & 12,1 & 3468,00 & 0,17 \\
\hline
\end{tabular}

Sumber: ${ }^{a}$ Dewi, F. (2014);

${ }^{b}$ Hasil analisis Lab Fakultas Peternakan, Universitas Andalas, (2018);

cPesik, H., et al (2015)

"Hasil analisis UPT Pengujian dan Sertifikasi Mutu Barang Prov. Riau (2018)

4. Penjemuran daun apu-apu dibawah sinar matahari selama 2-3 hari agar daun kering sempurna.

5. Penggilingan daun dengan mesin penggiling hingga menjadi tepung.

6. Tepung daun apu-apu siap dicampur dengan ransum basal.

\section{Peubah yang Diukur}

Peubah yang diukur pada penelitian ini adalah bobot proventrikulus, bobot ventrikulus, bobot usus halus dan panjang usus halus.

\section{HASIL DAN PEMBAHASAN}

\section{Bobot Proventrikulus}

Pengaruh pemberian tepung daun apu-apu dalam ransum basal terhadap bobot proventrikulus dapat dilihat pada Tabel 4 . Hasil analisis ragam menunjukkan bahwa pemberian tepung daun apu-apu dalam ransum basal sampai level 15\% pada ayam pedaging umur 35 hari tidak berpengaruh nyata $(\mathrm{P}>0,05)$ terhadap bobot proventrikulus ayam pedaging. Rataan bobot proventrikulus pada perlakuan pemberian tepung daun apuapu dari penelitian adalah antara 7,00-8,75 g. 
Tabel 2. Komposisi dan Kandungan Nutrisi Ransum Perlakuan Periode Starter

\begin{tabular}{lcccc}
\hline Bahan Pakan & & \multicolumn{3}{c}{ Ransum $(\%)$} \\
\hline Jagung & $\mathrm{T} 1$ & $\mathrm{~T} 2$ & $\mathrm{~T} 3$ & 39,00 \\
Bungkil Kedelai & 47,00 & 45,00 & 41,00 & 22,50 \\
TDA & 26,00 & 24,00 & 23,00 & 15,00 \\
Dedak Padi & 0,00 & 5,00 & 10,00 & 13,00 \\
Tepung Ikan & 15,50 & 15,50 & 14,50 & 8,00 \\
Minyak Sawit & 8,00 & 8,00 & 8,00 & 1,00 \\
CaCo3 & 2,00 & 1,00 & 2,00 & 1,00 \\
Top Mix & 1,00 & 1,00 & 1,00 & 0,50 \\
Total & 0,50 & 0,50 & 0,50 & 100,00 \\
Kandungan Nutrien: & 100,00 & 100,00 & 100,00 & $3.159,87$ \\
Energi Metabolis (kkal/kg) ${ }^{1)}$ & & & & 22,12 \\
Protein (\%) & $3.209,51$ & $3.216,37$ & $3.154,84$ & 6,40 \\
Lemak Kasar $(\%)$ & 22,86 & 22,40 & 22,08 & 6,74 \\
Serat Kasar $(\%)$ & 6,66 & 6,63 & 6,54 & 1,01 \\
Kalsium (\%) & 4,09 & 5,03 & 5,86 & 0,68 \\
Total P (\%) & 1,04 & 1,03 & 1,02 & 0,71 \\
\hline Keterangan Kandungan & 0,77 & 0,75 & &
\end{tabular}

Keterangan :Kandungan nutrisi merupakan hasil perhitungan Tabel 3

1) Protein dan energi metabolis (ME) disusun $22 \%$ dan $3.200 \mathrm{kkal}$ untuk periode pertumbuhan (0-5 minggu) modifikasi SNI 01-3907 (2006)

Hasil dari penelitian ini tidak jauh berbeda dengan hasil penelitian Wulandari (2012) bahwa berat organ proventrikulus pada ayam broiler umur 35 hari adalah $6,66-7,88$ g. Rataan persentase bobot proventrikulus pada penelitian ini sekitar $0,47-0,62 \%$. Hal tersebut tidakjauh berbeda dengan dengan hasil penelitian lain diantaranya menurut Mahmilia (2005) melaporkan bahwa persentase proventrikulus sebesar 0,320,34\%. Selain itu, Yaman (2010) melaporkan bahwa proventrikulus memiliki panjang $6 \mathrm{~cm}$ dan berat 7,5-10 g sedangkan menurut Usman dkk. (2010), bobot proventrikulus mencapai 0,47\% serta Sari dan Ginting (2012) menyatakan bahwa berat proventrikulus ayam broiler sekitar 0,44-0,64\%. Berdasarkan keterangan di atas, bobot proventrikulus dalam penelitian ini masih tergolong normal.

Hal yang diduga menyebabkan bobot proventrikulus tidak berbeda nyata adalah kandungan serat kasar antar perlakuan masih di dalam ambang batas optimal pada ayam ras pedaging, yakni dibawah $7 \% \mathrm{O}$

Ewing (1963) menyatakan bahwa batas toleransi kandungan serat kasar pada ransum adalah di bawah $7 \%$.

Tabel 3. Komposisi dan Kandungan Nutrisi Ransum Perlakuan Periode Finisher

\begin{tabular}{lcccc}
\hline \multirow{2}{*}{ Bahan Pakan } & \multicolumn{4}{c}{ Ransum (\%) } \\
\cline { 2 - 5 } & $\mathrm{T} 1$ & $\mathrm{~T} 2$ & $\mathrm{~T} 3$ & $\mathrm{~T} 4$ \\
\hline Jagung & 56,50 & 51,50 & 46,50 & 47,50 \\
Bungkil Kedelai & 23,00 & 23,00 & 23,00 & 22,00 \\
TDA & 0,00 & 5,00 & 10,00 & 15,00 \\
Dedak Padi & 10,00 & 10,00 & 10,00 & 5,00 \\
Tepung Ikan & 7,00 & 7,00 & 7,00 & 7,00 \\
Minyak Sawit & 2,00 & 2,00 & 2,00 & 2,00 \\
CaCo3 & 1,00 & 1,00 & 1,00 & 1,00 \\
Top Mix & 0,50 & 0,50 & 0,50 & 0,50 \\
\hline Total & 100,00 & 100,00 & 100,00 & 100,00 \\
\hline
\end{tabular}




\begin{tabular}{lcccc}
\hline Kandungan Nutrien: & & & \\
\hline Energi Metabolis (kkal/kg) ${ }^{1)}$ & $3.231,45$ & $3.297,94$ & $3.156,34$ & $3.145,18$ \\
Protein (\%) & 21,19 & 21,36 & 21,44 & 21,20 \\
Lemak Kasar (\%) & 5,98 & 6,00 & 6,46 & 5,53 \\
Serat Kasar (\%) & 3,72 & 4,67 & 5,88 & 6,24 \\
Kalsium (\%) & 0,99 & 0,98 & 0,97 & 0,96 \\
Total P (\%) & 0,74 & 0,71 & 0,67 & 0,65 \\
\hline
\end{tabular}

Keterangan : Kandungan nutrisi merupakan hasil perhitungan Tabel 3

1) Protein dan energi metabolis (ME) disusun $21 \%$ dan $3.200 \mathrm{kkal}$ untuk periode pertumbuhan (0-5 minggu) modifikasi SNI 01-3907 (2006)

\section{Bobot Ventrikulus}

Pengaruh pemberian tepung daun bobot ventrikulus dapat dilihat pada Tabel 5. apu-apu dalam ransum basal terhadap

Tabel 4. Rataan Bobot Proventrikulus Ayam Pedaging (g) Umur 35 Hari yangDiberiTepung Daun Apu-apu.

\begin{tabular}{lc}
\hline \multicolumn{1}{c}{ Perlakuan (\%) } & Bobot Proventrikulus (g) \\
\hline T0(Ransum Komersial) & $7,50 \pm 2,08$ \\
T1 (RB dengan TDA 0\%) & $7,00 \pm 0,82$ \\
T2 (RB dengan TDA 5\%) & $8,75 \pm 0,96$ \\
T3 (RB dengan TDA 10\%) & $7,50 \pm 0,58$ \\
T4 (RB dengan TDA 15\%) & $7,50 \pm 1,00$ \\
\hline
\end{tabular}

Keterangan: RB = Ransum Basal, TDA = Tepung Daun Apu-apu

Tabel 5. Rataan Bobot Ventrikulus Ayam Pedaging (g) Umur 35 Hari yang Diberi Tepung Daun Apu-apu.

\begin{tabular}{ll}
\hline \multicolumn{1}{c}{ Perlakuan (\%) } & Bobot Ventrikulus (g) \\
\hline T0 (Ransum Komersial) & $26,00 \pm 1,00$ \\
T1 (RB dengan TDA 0\%) & $32,50 \pm 4,04$ \\
T2 (RB dengan TDA 5\%) & $31,00 \pm 6,16$ \\
T3 (RB dengan TDA 10\%) & $34,50 \pm 3,11$ \\
T4 (RB dengan TDA 15\%) & $33,50 \pm 7,33$ \\
\hline
\end{tabular}

Keterangan: $\mathrm{RB}=$ Ransum Basal, $\mathrm{TDA}=$ Tepung Daun Apu-apu

Data yang ditampilkan adalah data rataan \pm standar deviasi

Hasil analisis sidik ragam menunjukan bahwa pemberian tepung daun apu-apu dalam ransum basal sampai level $15 \%$ pada ayam pedaging umur 35 hari tidak berpengaruh nyata $(\mathrm{P}>0,05)$ terhadap bobot ventrikulus ayam ras pedaging. Rataan bobot ventrikulus hasil penelitian yang diperoleh masih berada pada kisaran normal jika dibandingkan dengan pernyataan Yaman (2010), bahwa organ ventrikulus memiliki panjang 5 sampai $7,5 \mathrm{~cm}$ dan berat 25 - 30 gram. Wulandari (2012) menyatakan bahwa berat ventrikulus ayam broiler umur 35 hari sekitar 23,98-27,91 g. Menurut Daud dkk. (2016), yakni bobot ventrikulus ayam pedaging umur 35 hari yaitu sekitar 30,13-31,63 g. Nurhayati (2010) melaporkan bahwa berat ventrikulus ayam ras pedaging antara 20-23 gram.

Berat ventrikulus yang tidak berbeda nyata pada semua perlakuan tersebut diduga karena pakan yang diberi pada semua perlakuan berbentuk mash (tepung), sehingga ransum dapat dengan mudah digiling dan dipecah oleh ventrikulus menjadi ukuran yang lebih kecil. Pond et al. (1995) menyatakan bahwa pemberian pakan dalam bentuk tepung (mash) pada ayam broiler menyebabkan kerja proventrikulus tidak begitu maksimal, dimana fungsi ventrikulus adalah menggiling dan memecah partikel makanan menjadi ukuran yang lebih kecil. Akoso (1993) menambahkan bahwa besar kecilnya ventrikulus dipengaruhi oleh aktivitasnya, 
Tabel 6. Rataan Bobot Usus Halus Ayam Pedaging (g) Umur 35 Hari yang Diberi Tepung Daun Apu-apu.

\begin{tabular}{ll}
\hline Perlakuan (\%) & Bobot Usus Halus (g) \\
\hline T0 (Ransum Komersial) & $44,33 \pm 6,81$ \\
T1 (RB dengan TDA 0\%) & $48,33 \pm 1,15$ \\
T2 (RB dengan TDA 5\%) & $50,00 \pm 3,00$ \\
T3 (RB dengan TDA 10\%) & $56,00 \pm 9,42$ \\
T4 (RB dengan TDA 15\%) & $61,50 \pm 14,39$ \\
\hline
\end{tabular}

Keterangan: RB= Ransum Basal, TDA= Tepung Daun Apu-apu

Data yang ditampilkan adalah data rataan \pm standar deviasi

\section{Bobot Usus Halus}

Pengaruh pemberian tepung daun apu-apu dalam ransum basal terhadap bobot ventrikulus dapat dilihat pada Tabel 6. Hasil analisis sidik ragam menunjukkan bahwa pemberian tepung daun apu-apu dalam ransum basal sampai level 15\% pada ayam ras pedaging umur 35 hari tidak berpengaruh nyata $(\mathrm{P}>0,05)$ terhadap bobot usus halus ayam pedaging. Rata-rata bobot usus dari bobot hidup. Penelitian ini sesuai dengan pendapat Resnawati (1986), bahwa bobot usus halus ayam pedaging berkisar antara 4,01-4,78\% dari bobot hidup. Namun lebih rendah jika dibandingkan dengan yang dilaporkan oleh Hermana et al. (2005), yang berkisar antara 5,55-7,33\% dari bobot hidup. Menurut Daud dkk. (2016), bobot usus halus kisaran 41,63-46,50 g. Berdasarkan penjelasan di atas, bobot usus halus dalam penelitian ini masih tergolong normal. Hal ini berarti bahwa fungsi penyerapan dan transportasi zat-zat nutrisi pada usus halus tidak terganggu dengan adanya pemberian tepung daun apu-apu

Faktor penyebab lainnya diduga karena kandungan serat kasar pada masingmasing perlakuan masih dapat ditoleransi oleh saluran pencernaan usus halus. Peningkatan jumlah serat kasar di dalam ransum secara statistik tidak menunjukkan adanya pengaruh peningkatan bobot usus halus sementara secara deskriptif terdapat perbedaan terhadap bobot usus halus. Hal ini kemungkinan disebabkan laju pencernaan menjadi lambat karena serat kasar pada ransum membutuhkan pencernaan pakan lebih intensif. Laju digesta yang lambat menghidrolisis zat makanan lebih lama sehingga penyerapan zat-zat makanan akan efektif dan kecernaan pakan akan meningkat. Faktor lain adalah kandungan protein kasar yang hampir sama pada setiap perlakuan. Menurut Naufa (2013), menyatakan bahwa peningkatan level protein ransum ayam kedu periode bertelur dari 12 sampai 16\% meningkatkan bobot relatif esophagus, usus halus, sekum dan kolon namun tidak berpengaruh nyata terhadap peningkatan bobot ventrikulus. Hal ini sejalan dengan peningkatan fungsi usus untuk menyerap nutrisi pada ransum.

\section{Panjang Usus Halus}

Pengaruh pemberian tepung daun apu-apu dalam ransum basal terhadap bobot ventrikulus dapat dilihat pada Tabel 7. Hasil analisis sidik ragam menunjukkan bahwa pemberian tepung daun apu-apu dalam ransum basal sampai level $15 \%$ pada ayam pedaging umur 35 hari tidak berpengaruh nyata $(\mathrm{P}>0,05)$ terhadap panjang usus halus ayam ras pedaging. Rata-rata panjang usus halus pada penelitian adalah sekitar antara $170,75-187,00 \mathrm{~cm}$.

Hasil penelitian ini lebih rendah dibandingkan dengan yang dilaporkan Sturkie (1986), bahwa panjang normal usus halus ayam broiler adalah $179,6 \mathrm{~cm}$. Menurut Puspitasari (2006), panjang usus halus ayam pedaging umur 35 hari adalah sekitar 17,13$19,80 \%$ dari bobot hidup, ditambahkan pernyataan Noferdiman (2012), bahwa panjang usus halus ayam pedaging umur 5 minggu antara 193,1 - 201,3 cm. Dilihat dari panjang usus halus yang dihasilkan dari penelitian ini, bobot masih dalam taraf normal.

Berdasarkan penjelasan diatas, beberapa dugaan mengapa penggunaan 
tepung daun apu-apu dalam ransum basal berpengaruh terhadap panjang usus halus pada penelitian ini: 1) diduga karena serat kasar yang terkandung di dalam ransum masih dalam taraf optimal yakni dibawah $7 \%$ sehingga aktifitas pencernaan didalam usus halus juga tidak mengalami perubahan pada panjang usus halus. Sementara itu, juga diduga kandungan nutrisi daun apuapu sampai pada level 15\% didalam ransum tersebut dapat dimanfaatkan dengan baik oleh organ pencernaan yakni usus halus.

Tabel 7. Rataan Panjang Usus Halus Ayam Pedaging Umur 35 Hari yang Diberi Tepung Daun Apuapu.

\begin{tabular}{lc}
\hline Perlakuan $(\%)$ & Panjang Usus Halus $(\mathrm{cm})$ \\
\hline T0 (Ransum Komersial) & $177,25 \pm 7,80$ \\
T1 (RB dengan TDA 0\%) & $170,75 \pm 5,56$ \\
T2 (RB dengan TDA 5\%) & $177,00 \pm 8,52$ \\
T3 (RB dengan TDA 10\%) & $179,00 \pm 2,00$ \\
T4 (RB dengan TDA 15\%) & $187,00 \pm 4,62$ \\
\hline
\end{tabular}

Keterangan: $\mathrm{RB}=$ Ransum Basal, TDA= Tepung Daun Apu-apu

Data yang ditampilkan adalah data rataan \pm standar deviasi

\section{KESIMPULAN}

\section{Kesimpulan}

Pemberian tepung daun apu-apu (Pistia stratiotes) dalam ransum basal sapai level 15\% dapat mempertahankan persentase bobot proventrikulus, bobot ventrikulus, bobot usus halus serta panjang usus halus ayam ras pedaging.

\section{DAFTAR PUSTAKA}

Akoso. 1993. Manual Kesehatan Unggas. Kanisius. Yogyakarta.

Budiarti, A. S. 2018. Pengaruh lama fermentasi duckweed (lemna minor) menggunakan mixed culture terhadap kadar protein dan serat kasar. Skripsi. Program Studi Peternakan, Fakultas Peternakan Universitas Mataram. Mataram

Daud, M., Zulfan, \& Syafriadi. 2016. Pengaruh substitusi ransum komersial dengan tepung kulit pisang fermentasi + feed suplement terhadap berat dan persentase organ dalam ayam broiler. Jurnal Ilmiah Mahasiswa Pertanian Unsyiah. 1 (1): 671684.

Ewing, W. R. 1963. Poultry Nutrition, 5th Ed. The Pay Ewing Company, Pasadena, California.

Goopy J. P \& P. J. Murray. 2003. A Review on the role of duckweed in nutrient reclamation and as a source of animal feed. AsianAust. J. Anim. Sci. 16(2 ): 297-305.
Haustein, A. T., R. H. Gilman, P. Skillicorn, V. Vergara, V.Guevera \& A. Gastanaduy. 1990. Duckweed, a useful strategy for feeding chickens: performance of layers fed with sewage grown Lemnacae species. Poult. Sci. 69: 329-35.

Hermana, W., D. I. Puspitasari, K. G. Wiryawan, \& S. Suharti. 2008. Pemberian tepung daun salam (Syzygium polyanthum (Wight) Walp.) dalam ransum sebagai bahan antibakteri terhadap persentase bobot saluran pencernaan. Media Peternakan. 31(1): 63-70.

Iyayi E. A., O. Ogunsola, \& R. Ijaya. 2005. Effect of three sources of fibre and period of feeding on the performance, carcase measures, organs relative weight and meat quality in broilers. International Journal of Poultry Science. 4(9): 695-700.

Mahmilia, F. 2005. Perubahan nilai gizi tepung eceng gondok fermentasi dan pemanfaatannya sebagai ransum ayam pedaging. JITV. 10(2): 90-95.

Naufa, A. M., H. I. Wahyuni \& I. Mangisah. 2013. Bobot Relatif Organ Pencernaan Ayam Kedu Petelur Diberi Ransum dengan berbagai Level Protein. Makalah Jurnal. Universitas Diponegoro, Semarang.

Noferdiman. 2012. Efek penggunaan Azolla microphylla fermentasi sebagai pengganti bungkil kedele dalam ransum terhadap bobot organ pencernaan ayam broiler. Jurnal Penelitian Universitas Jambi Seri Sains. 14(1): 49-56. 
Pond, W. G., D. C. Church, \& K. R. Pond. 1995. Basic Animal Nutrition and Feeding. $4^{\text {th }}$ Edition. John Willey and Sons, New York. Radic Res : 26(1): 63-70.

Puspitasari, D. I. 2006.Kajian Pemberian Tepung Daun Salam (Syzygium polyanthum) (wight) Walp.) dalam Ransum sebagai Bahan Anti Bakteri Escherchia coli terhadap Organ Dalam Ayam Broiler. Skripsi. Fakultas Peternakan. Institut Pertanian Bogor. Bogor.

Nurhayati. 2010. Pengaruh penggunaaan tepung buah mengkudu terhadap bobot organ pencernaan ayam pedaging. Agripet (10) No. 2: 40-44

O'Neill, P. J., J. V. Nolan, \& E. Thomson. 1996. Duckweed as an alternative to Soyabean Meal in Diets for High-Producing Layers. Proc. Poultry Foundation Meeting Sydney. Resnawati, H. 1986. Pemanfaatan Biji Saga Pohon (Adenanthera povonona L.) sebagai Bahan Makanan dalam Ransum Ayam Pedaging. Disertasi. Pascasarjana Institut Pertanian Bogor. Bogor.

Rusoff, L. L., E. W. Blakney, \& D. D. Culley. 1980. Duckweeds (Lemnacae Family): A potential source of protein and amino acids. J. Agric. Food Chem. 28: 848-50.

Sari, M.L., \& F.G.N. Ginting. 2012. Pengaruh Penambahan Enzim Fitase pada Ransum terhadap Berat Relatif Organ Pencernaan Ayam Broiler. Agripet. 12(2): 37-41.

Situmorang,N.A.,L.DMahfudz, \& Atmomarsono. 2013. Pengaruh pemberian tepung rumput laut (Gracia verrucosa) dalam ransum terhadap effisiensi penggunaan protein ayam broiler. Animal Agricultural Journal. 2(2): 49-56.

Sturkie, P. D. 1976. Avian Physiologi .3rd Ed. Spinger-Verlag. New York.

Sutama, I.N.S. 2005.Pengaruh Suplementasi Kapu-Kapu (Pistia stratiotes L) dalam Ransum terhadap Kolesterol pada Serum dan Daging Ayam Kampung. Udayana. Bali.

Usman, Ahmad \& N. Rahmadai. 2010. Pertumbuhan Ayam Broiler (Melalui Sistem Pencernaannya) yang Diberi Pakan Nabati dan Komersial dengan Penambahan Dysapro. Institut Pertanian Bogor. Bogor.

Yaman, M. A. 2010. Ayam Kampung Unggul. Penebar Swadaya. Jakarta.
Wulandari, M. 2012. Pengaruh Pemberian Asam Fulfat dalam Ransum terhadap Bobot Karkas, Organ Dalam dan Kolesterol Daging Ayam Broiler. Skripsi. Fakultas Peternakan, Institut Pertanian Bogor. Bogor 